\title{
Effects of Soy Protein Isolate and Inulin on Physico-chemical and Organoleptic Qualities of Low-fat Duck Meat Sausages
}

\author{
S. Moirangthem, S.K. Laskar, A. Das, S. Upadhyay, M. Hazarika, R.A. Hazarika1', J.D. Mahanta² $\quad$ 10.18805/ajdfr.DR-1828
}

\begin{abstract}
Background: The present work was conducted to study the effect of incorporation of soy protein isolate (SPI) and Inulin (I) on certain Physico-chemical and sensory qualities of low-fat duck meat sausages.

Methods: Duck meat sausages were prepared by using three different formulations i.e. $\mathrm{T}_{1}(2.5 \% \mathrm{I}), \mathrm{T}_{2}(2.5 \% \mathrm{SPI})$ and $\mathrm{T}_{3}(2.5 \%$ $\mathrm{SPI}+2.5 \% \mathrm{I})$ along with a control $\left(\mathrm{C}_{\mathrm{T}}-0 \% \mathrm{SPI}\right.$ and $\left.\mathrm{I}\right)$. The $\mathrm{pH}$, water holding capacity, TBARS value, tyrosine value and sensory qualities were evaluated on days 1,5 and 10 .

Result: Duck meat sausages with a combination of $2.5 \%$ soy protein isolate and $2.5 \%$ inulin were the best ones, with a shelf-life of 10 days under refrigeration.
\end{abstract}

Key words: Duck meat, Low-fat, Physicochemical study, Sensory qualities.

\section{INTRODUCTION}

In the modern meat processing industry, the ever-increasing market competitiveness has led to the development of various meat products with some health-beneficial effects, including lower fat content.

Duck meat is highly preferred in Asia and Europe. According to India's $20^{\text {th }}$ Livestock Census Report, the total population of ducks in the country is 33.511 million, out of which Assam has 12.04 million ducks. Duck meat has high demand in Northeastern region of the country.The first step in developing healthy meat products is to reduce the highfat content of the most popular processed meat products (Brewer, 2012). However, developing consumer-acceptable low-fat meat products is a challenge because fat provides desirable quality attributes (Kumar, 2019). Replacement of a significant amount of fat by thickening agents/meat extenders such as soy protein isolate provides lubricity, solubility and swelling. A fat mimick system influences texture properties in low-fat food (Ahmad et al., 2010). In this context, Inulin can be used as a fat replacer in food products because it can form a gel when mixed with water. The resulting gel has a fine, creamy texture that mimics the oral tactile sensation of fat in products with low-fat content (Janvary, 2008).

Sausages are ready-to-eat meat products, popular universally due to variety and convenience to the consumers. Duck meat is the third most widely produced poultry meat globally after chicken and turkey (Matitaputty et al., 2015). Therefore, the pessent study was undertaken with an objective for preparing duck meat sausages with reduced fat content incorporating Inulin and SPI.

\section{MATERIALS AND METHODS}

The local ducks (Pati) were obtained from the nearby market (Beltola). The birds were scientifically slaughtered following welfare ethics in the poultry-dressing unit of the Department
Department of Livestock Products Technology, College of Veterinary Science, Assam Agricultural University, Guwahati-781 022, Assam, India.

${ }^{1}$ Department of Veterinary Public Health, College of Veterinary Science, Assam Agricultural University, Guwahati-781 022, Assam, India.

2Department of Poultry Science, College of Veterinary Science, Assam Agricultural University, Guwahati-781 022, Assam, India.

Corresponding Author: S.K. Laskar, Department of Livestock Products Technology, College of Veterinary Science, Assam Agricultural University, Guwahati-781 022, Assam, India.

Email: saurabhlaskar@gmail.com

How to cite this article: Moirangthem, S., Laskar, S.K., Das, A., Upadhyay, S., Hazarika, M., Hazarika, R.A. and Mahanta, J.D. (2022). Effects of Soy Protein Isolate and Inulin on Physico-chemical and Organoleptic Qualities of Low-fat Duck Meat Sausages. Asian Journal of Dairy and Food Research. DOI: 10.18805/ajdfr.DR-1828.

Submitted: 26-10-2021 Accepted: 12-01-2022 Online: 03-03-2022

of Livestock Products Technology, College of Veterinary Science, Khanapara. After that, it was deboned and the lean was separated and vacuum-packed in high-density polyethylene (HDPE) bags and stored at refrigeration temperature $\left(4 \pm 1^{\circ} \mathrm{C}\right)$. Fats present in the abdominal cavity, visceral fats and subcutaneous fats along with skin were separated and boiled with sufficient quantity of water to melt the fat. After proper cooling the melted fat was separated by using a separating funnel and stored for later use. Good quality food-grade soy protein isolate (SPI) and Inulin were purchased from a local supermarket.

The deboned meat was minced twice in a mechanical meat mincer and thoroughly mixed with the curing ingredients, viz. salt $(1.75 \%)$, sugar $(0.5 \%)$ and sodium nitrite $(150 \mathrm{ppm})$ before storing at refrigeration temperature for 24 hrs. After that the sausage emulsion was prepared in a bowl 
chopper with the required amount of fat, non-meat ingredients, spices and condiments. The emulsion thus prepared was divided into four parts. Excepting the control emulsion (C), the other three parts of emulsions were thoroughly mixed with $2.5 \%$ Inulin $\left(\mathrm{T}_{1}\right), 2.5 \%$ Soy protein isolate $\left(\mathrm{T}_{2}\right)$ and $2.5 \%$ Soy protein isolate and $2.5 \%$ inulin $\left(T_{3}\right)$, respectively, before stuffing into the cellulose casings. Subsequently, the raw sausages were cooked in water in a cooking vat at $80-85^{\circ} \mathrm{C}$ for 45 minutes.

Soon after cooking, the hot sausages were immersed in chilled water. The chilled sausages were peeled and packaged into food-grade HDPE bags and stored under refrigeration to evaluate the different qualitative traits on $1^{\text {st }}$, $5^{\text {th }}$ and $10^{\text {th }}$ day of storage. Altogether, five batches of sausages were prepared for the present study.

The emulsion stability (ES) was detected by the method described by Mongale et al. (1985), while the cooking yield (CY) was recorded as per standard protocol and expressed as a percentage.:

$$
\text { Cooking yield }=\frac{\text { Weight of cooked product }}{\text { Weight of raw product }} \times 100
$$

The water holding capacity (WHC) was measured by the technique described by Wardlaw et al. (1973), while the $\mathrm{pH}$ of the sausages was determined by the method of Pippen et al. (1965). The TBARS value of the sausages was determined as per Witte et al. (1970) while tyrosine value was determined by a modified method of Pearson and Gillett (1996) as described by Strange et al. (1977). The calorie value $(\mathrm{CV})$ of the cooked sausages was calculated based on 100 portions using the Atwater value for fat $(9.00 \mathrm{kcal} / \mathrm{g})$, protein $(4.02 \mathrm{kcal} / \mathrm{g})$ and carbohydrate $(4.00 \mathrm{kcal} / \mathrm{g})$. The sensory qualities of the sausages were evaluated using a 9-point hedonic scale as described by Bratzler (1971). The data obtained from the above study were analysed statistically by the software SAS (SAS 9.3 software).

\section{RESULTS AND DISCUSSION}

\section{Physico-chemical qualities}

The treated sausages with SPI and I recorded significantly $(p<0.01)$ higher ES in comparison to Control and $T_{3}$ containing SPI and I @ 2.5\% each showed the highest (Table 1). This increased ES might be because dietary fiber like Inulin can lead to a compact gel formation due to the fibers ability to retain fat and water (Fernández et al., 2005).
The treated formulation showed a significantly higher $(p<0.01)$ CY than the control (Table 1) and might be due to the fibers in Inulin which can retain water and can form a barrier against fat absorption while cooking (Kılınççeker and Kurt 2018). A significantly higher cooking yield was also observed with increasing soy protein addition in chevon patties by Yadav et al. (2013).

A gradual significant $(p<0.01)$ increment in WHC in the treated sausages was noted than the control product (Table 1), which might be due to increased water retention by increased levels of I and SPI. Fernandez et al. (2005) reported that SPI has an outstanding ability to bind with water and enhance the WHC and solubility of emulsified meat. Similar findings were also reported by Mendez et al. (2015).

The significantly $(p<0.01)$ low calorie value was observed in treated formulations due to the replacement of fat and simultaneous substitution with SPI and I. Similar results were also observed by Kumar et al. (2004) by reducing fat content from 15 to 10 percent in low fat pork patties and by Garcia et al. (2006) in reduced-fat sausages (10\% fat) incorporated with Inulin.

The $\mathrm{pH}$ values of duck meat sausages with I recorded a significant $(p<0.01)$ decrease. In contrast, the addition of SPI significantly $(p<0.01)$ increased the $\mathrm{pH}$ values of the products than the control (Table 2). Reduced $\mathrm{pH}$ in sausages added with I may be attributed to low ionic strength, the chemical composition of dietary fiber and the protein content of the polysaccharides (Méndez et al. (2015). The higher pH of SPI-treated sausages might be due to SPI's high pH (7.52) (Lee et al., 2017).

Significant differences $(p<0.01)$ in the TBARS values among control and treated formulations were noted. There was also a gradual increase in TBARS values with the advancement in storage (Table 2). However, sausages with Inulin showed lower TBARS value than other formulations, which might be due to lower fat content than control. Jairath et al. (2018) also observed significantly lower TBARS values in buffalo calf meat sausages incorporated with corn starch as fat replacers. The gradual increase in TBARS values on storage might be attributed to oxygen permeability of packaging material that led to lipid oxidation and production of volatile metabolites during the storage period (Kumar et al., 2013).

The tyrosine value of the treated sausages with SPI and I revealed a significant $(p<0.01)$ increase during the storage period in the control and treated products. However,

Table 1: Emulsion stability (ES) (ml of oil/100 g of emulsion), cooking yield (\%), water holding capacity (WHC) and calorie value (Kcal/ $100 \mathrm{~g}$ ) of duck meat sausages incorporated with SPI and I (Mean \pm SE).

\begin{tabular}{lcccc}
\hline Treatments/Parameters & Control $(0 \%)$ & $\mathrm{T}_{1}(1 \%)$ & $\mathrm{T}_{2}(3 \%)$ & $\mathrm{T}_{3}(5 \%)$ \\
\hline Emulsion Stability & $2.54^{\mathrm{a}} \pm 0.04$ & $2.28^{\mathrm{b}} \pm 0.02$ & $2.1^{\mathrm{c}} \pm 0.04$ & $1.7^{\mathrm{d}} \pm 0.03$ \\
Cooking Yield & $90.42^{\mathrm{a}} \pm 0.28$ & $92.15^{\mathrm{b}} \pm 0.06$ & $93.25^{\mathrm{c}} \pm 0.11$ & $94.75^{\mathrm{d}} \pm 0.15$ \\
Water Holding Capacity & $41.78^{\mathrm{a}} \pm 1.25$ & $47.95^{\mathrm{b}} \pm 1.05$ & $48.93^{\mathrm{c}} \pm 1.33$ & $49.72^{\mathrm{d}} \pm 1.49$ \\
Calorie Value & $205.87^{\mathrm{a}} \pm 1.63$ & $180.64^{\mathrm{b}} \pm 0.98$ & $180.99^{\mathrm{b}} \pm 1.48$ & $165.94^{\mathrm{c}} \pm 2.42$ \\
\hline
\end{tabular}

$\mathrm{N}=5$, Mean with superscript bearing different alphabet (small) row-wise differ significantly. 
Effects of Soy Protein Isolate and Inulin on Physico-chemical and Organoleptic Qualities of Low-fat Duck Meat Sausages

no significant difference $(p>0.05)$ was observed between control and treated formulations. During storage, the increase in tyrosine values might be due to the inherent enzymes of meat and bacterial proteolysis (Strange et al., 1977).

\section{Organoleptic qualities}

Incorporation of SPI and I significantly $(p<0.01)$ increased the appearance, colourand flavour scores in treated groups than the control (Table 3). Alaei et al. (2018) and Ahmad

Table 2: Effect of incorporation of SPI and I on pH, TBARS value ( $\mathrm{mg}$ malonaldehyde/kg) and tyrosine value (mg tyrosine/100 $\mathrm{g}$ ) of duck meat sausages (Mean \pm SE).

\begin{tabular}{lcccc}
\hline Treatment & Days & $\mathrm{pH}$ & $\begin{array}{c}\text { TBA } \\
\text { (mg malonaldehy de/kg) }\end{array}$ & $\begin{array}{c}\text { Tyrosine value } \\
(\mathrm{mg} \text { tyrosine/100 } \mathrm{g} \text { ) }\end{array}$ \\
\hline Control & 1 & ${ }^{\mathrm{A}} 0.311^{\mathrm{a}} \pm 0.00$ & ${ }^{\mathrm{A}} 15.816 \pm 0.26$ \\
& 5 & ${ }^{\mathrm{A}} 6.23^{\mathrm{a}} \pm 0.04$ & ${ }^{\mathrm{B}} 0.525^{\mathrm{a}} \pm 0.00$ & ${ }^{\mathrm{AB}} 17.999 \pm 0.19$ \\
& 10 & ${ }^{\mathrm{A}} 6.13^{\mathrm{a}} \pm 0.03$ & ${ }^{\mathrm{C}} 0.730^{\mathrm{a}} \pm 0.00$ & ${ }^{\mathrm{B}} 18.667 \pm 0.24$ \\
$\mathrm{~T}_{1}$ & 1 & ${ }^{\mathrm{B}} 5.93^{\mathrm{ab}} \pm 0.00$ & ${ }^{\mathrm{A}} 0.281^{\mathrm{b}} \pm 0.00$ & ${ }^{\mathrm{A}} 16.148 \pm 0.24$ \\
& 5 & ${ }^{\mathrm{A}} 6.08^{\mathrm{b}} \pm 0.05$ & ${ }^{\mathrm{B}} 0.436^{\mathrm{b}} \pm 0.00$ & ${ }^{\mathrm{AB}} 18.176 \pm 0.18$ \\
$\mathrm{~T}_{2}$ & 10 & ${ }^{\mathrm{A}} 6.00^{\mathrm{b}} \pm 0.06$ & ${ }^{\mathrm{C}} 0.639^{\mathrm{b}} \pm 0.00$ & ${ }^{\mathrm{B}} 19.052 \pm 0.25$ \\
& 1 & ${ }^{\mathrm{B}} 5.84^{\mathrm{a}} \pm 0.02$ & ${ }^{\mathrm{A}} 0.283^{\mathrm{b}} \pm 0.00$ & ${ }^{\mathrm{A}} 16.773 \pm 0.31$ \\
$\mathrm{~T}_{3}$ & 5 & ${ }^{\mathrm{A}} 6.29^{\mathrm{a}} \pm 0.03$ & ${ }^{\mathrm{B}} 0.436^{\mathrm{b}} \pm 0.00$ & ${ }^{\mathrm{A}} 18.738 \pm 0.21$ \\
& 10 & ${ }^{\mathrm{A}} 6.22^{\mathrm{a}} \pm 0.03$ & ${ }^{\mathrm{a}} 0.639^{\mathrm{b}} \pm 0.00$ & ${ }^{\mathrm{B}} 19.963 \pm 0.27$ \\
& 1 & ${ }^{\mathrm{B}} 5.97^{\mathrm{b}} \pm 0.01$ & ${ }^{\mathrm{A}} 0.271^{\mathrm{c}} \pm 0.00$ & ${ }^{\mathrm{A}} 16.275 \pm 0.24$ \\
& 5 & ${ }^{\mathrm{A}} 6.26^{\mathrm{a}} \pm 0.03$ & ${ }^{\mathrm{B}} 0.400^{\mathrm{C}} \pm 0.01$ & ${ }^{\mathrm{AB}} 18.503 \pm 0.40$ \\
& 10 & ${ }^{\mathrm{A}} 6.15^{\mathrm{a}} \pm 0.02$ & ${ }^{\mathrm{C}} 0.516^{\mathrm{c}} \pm 0.00$ & ${ }^{\mathrm{B}} 19.559 \pm 0.48$ \\
\hline
\end{tabular}

$\mathrm{N}=5$, Mean with subscript bearing different alphabet (small) row-wise differ significantly.

Mean with superscript bearing different alphabet (capital) column-wise differ significantly.

Table 3: Effect of incorporation of SPI and I on Sensory qualities of Duck meat sausages (Mean \pm SE).

\begin{tabular}{|c|c|c|c|c|}
\hline \multirow{2}{*}{ Parameters } & \multirow{2}{*}{ Treatments } & \multicolumn{3}{|c|}{ Storage days } \\
\hline & & Day 1 & Day 5 & Day 10 \\
\hline \multirow[t]{4}{*}{ Appearance } & Control & ${ }^{A} 6.29^{a} \pm 0.09$ & ${ }^{A B} 6.08^{a} \pm 0.09$ & ${ }^{\mathrm{B}} 5.90^{\mathrm{a}} \pm 0.08$ \\
\hline & $\mathrm{T}_{1}$ & ${ }^{\mathrm{A}} 6.60^{\mathrm{b}} \pm 0.06$ & ${ }^{\mathrm{B}} 6.28^{\mathrm{a}} \pm 0.03$ & ${ }^{\mathrm{B}} 6.04^{\mathrm{a}} \pm 0.04$ \\
\hline & $\mathrm{T}_{2}$ & $\mathrm{~A} 7.06^{\mathrm{c}} \pm 0.11$ & ${ }^{\mathrm{B}} 6.74^{\mathrm{b}} \pm 0.06$ & ${ }^{\mathrm{B}} 6.54^{\mathrm{b}} \pm 0.06$ \\
\hline & $\mathrm{T}_{3}$ & ${ }^{\mathrm{A}} 7.09^{\mathrm{cd}} \pm 0.04$ & ${ }^{\mathrm{AB}} 6.82^{\mathrm{b}} \pm 0.09$ & ${ }^{\mathrm{B}} 6.62^{\mathrm{b}} \pm 0.09$ \\
\hline \multirow[t]{4}{*}{ Colour } & Control & ${ }^{A} 6.45^{\mathrm{a}} \pm 0.10$ & ${ }^{\mathrm{AB}} 6.31^{\mathrm{a}} \pm 0.11$ & ${ }^{\mathrm{B}} 6.11^{\mathrm{a}} \pm 0.04$ \\
\hline & $\mathrm{T}_{1}$ & ${ }^{\mathrm{A}} 6.45^{\mathrm{a}} \pm 0.12$ & ${ }^{\mathrm{A}} 6.41^{\mathrm{a}} \pm 0.10$ & ${ }^{\mathrm{B}} 6.29^{\mathrm{a}} \pm 0.04$ \\
\hline & $\mathrm{T}_{2}$ & ${ }^{\mathrm{A}} 6.65^{\mathrm{ab}} \pm 0.08$ & ${ }^{\mathrm{A}} 6.49^{\mathrm{a}} \pm 0.09$ & ${ }^{\mathrm{B}} 6.42^{\mathrm{ab}} \pm 0.09$ \\
\hline & $\mathrm{T}_{3}$ & ${ }^{\mathrm{A}} 6.84^{\mathrm{b}} \pm 0.06$ & ${ }^{\mathrm{A}} 6.66^{\mathrm{ab}} \pm 0.09$ & ${ }^{\mathrm{B}} 6.55^{\mathrm{ab}} \pm 0.06$ \\
\hline \multirow[t]{4}{*}{ Flavour } & Control & ${ }^{\mathrm{A}} 6.25^{\mathrm{a}} \pm 0.15$ & ${ }^{\mathrm{AB}} 6.01^{\mathrm{a}} \pm 0.10$ & ${ }^{\mathrm{B}} 5.80^{\mathrm{a}} \pm 0.01$ \\
\hline & $\mathrm{T}_{1}$ & ${ }^{\mathrm{A}} 6.70^{\mathrm{b}} \pm 0.09$ & ${ }^{\mathrm{AB}} 6.42^{\mathrm{b}} \pm 0.03$ & ${ }^{\mathrm{B}} 6.19^{\mathrm{ab}} \pm 0.02$ \\
\hline & $\mathrm{T}_{2}$ & ${ }^{\mathrm{A}} 6.68^{\mathrm{b}} \pm 0.23$ & ${ }^{\mathrm{AB}} 6.31^{\mathrm{ab}} \pm 0.07$ & ${ }^{\mathrm{B}} 6.13^{\mathrm{ab}} \pm 0.05$ \\
\hline & $\mathrm{T}_{3}$ & ${ }^{A} 6.88^{b} \pm 0.08$ & ${ }^{\mathrm{AB}} 6.61^{\mathrm{b}} \pm 0.07$ & ${ }^{\mathrm{B}} 6.32^{\mathrm{b}} \pm 0.07$ \\
\hline \multirow[t]{4}{*}{ Texture } & Control & ${ }^{A} 6.26^{\mathrm{a}} \pm 0.09$ & ${ }^{\mathrm{A}} 6.12^{\mathrm{a}} \pm 0.13$ & в5.88a \pm 0.15 \\
\hline & $\mathrm{T}_{1}$ & ${ }^{\mathrm{A}} 6.65^{\mathrm{ab}} \pm 0.17$ & ${ }^{A} 6.58^{a} \pm 0.09$ & ${ }^{\mathrm{B}} 6.43^{\mathrm{ab}} \pm 0.09$ \\
\hline & $\mathrm{T}_{2}$ & ${ }^{A} 6.97^{\mathrm{bc}} \pm 0.13$ & ${ }^{\mathrm{A}} 6.70^{\mathrm{a}} \pm 0.06$ & ${ }^{\mathrm{B}} 6.44^{\mathrm{ab}} \pm 0.07$ \\
\hline & $\mathrm{T}_{3}$ & A7. $38^{\mathrm{c}} \pm 0.16$ & $\mathrm{~A} 7.30^{\mathrm{b}} \pm 0.21$ & ${ }^{\mathrm{B}} 6.82^{\mathrm{b}} \pm 0.29$ \\
\hline \multirow[t]{4}{*}{ Juiciness } & Control & ${ }^{\mathrm{A}} 6.56^{\mathrm{a}} \pm 0.07$ & ${ }^{\mathrm{AB}} 6.23^{\mathrm{a}} \pm 0.01$ & ${ }^{\mathrm{B}} 6.06^{\mathrm{a}} \pm 0.03$ \\
\hline & $\mathrm{T}_{1}$ & ${ }^{\mathrm{A}} 6.52^{\mathrm{a}} \pm 0.10$ & ${ }^{\mathrm{AB}} 6.29^{\mathrm{a}} \pm 0.04$ & ${ }^{\mathrm{B}} 6.10^{\mathrm{a}} \pm 0.06$ \\
\hline & $\mathrm{T}_{2}$ & ${ }^{\mathrm{A}} 6.75^{\mathrm{ab}} \pm 0.08$ & ${ }^{A B} 6.49^{\mathrm{a}} \pm 0.06$ & ${ }^{\mathrm{B}} 6.27^{\mathrm{a}} \pm 0.04$ \\
\hline & $\mathrm{T}_{3}$ & ${ }^{\mathrm{A}} 7.13^{\mathrm{b}} \pm 0.13$ & ${ }^{\mathrm{A}} 7.03^{\mathrm{b}} \pm 0.20$ & ${ }^{\mathrm{B}} 6.84^{\mathrm{b}} \pm 0.16$ \\
\hline \multirow[t]{4}{*}{ Overall acceptability } & Control & ${ }^{A} 6.24^{\mathrm{a}} \pm 0.06$ & ${ }^{\mathrm{AB}} 6.02^{\mathrm{a}} \pm 0.02$ & ${ }^{\mathrm{B}} 5.86^{\mathrm{a}} \pm 0.03$ \\
\hline & $\mathrm{T}_{1}$ & ${ }^{\mathrm{A}} 6.53^{\mathrm{b}} \pm 0.12$ & ${ }^{\mathrm{AB}} 6.21^{\mathrm{ab}} \pm 0.01$ & ${ }^{\mathrm{B}} 6.04^{\mathrm{ab}} \pm 0.02$ \\
\hline & $\mathrm{T}_{2}$ & ${ }^{\mathrm{A}} 6.78^{\mathrm{b}} \pm 0.10$ & ${ }^{\mathrm{B}} 6.45^{\mathrm{b}} \pm 0.02$ & ${ }^{\mathrm{B}} 6.23^{\mathrm{b}} \pm 0.02$ \\
\hline & $\mathrm{T}_{3}$ & ${ }^{A} 7.05^{\complement} \pm 0.05$ & ${ }^{\mathrm{AB}} 6.84^{\mathrm{C}} \pm 0.09$ & ${ }^{\mathrm{B}} 6.64^{\mathrm{C}} \pm 0.09$ \\
\hline
\end{tabular}

$\mathrm{N}=5$, Mean with subscript bearing different alphabet (small) column-wise differ significantly. Mean with superscript bearing different alphabet (capital) row-wise differ significantly. 
et al. ( 2010) also reported similar results in chicken sausage and buffalo meat sausages treated with I and SPI. Lee et al. (2017) reported improved flavour in breakfast sausage enhanced with $1 \%$ wheat sprout protein and $1 \%$ SPI.

The sausages incorporated with SPI and I revealed significantly $(p<0.05)$ higher texture and juiciness scores than the control, which might be due to the water-binding properties of SPI and I in treated formulations. Similar findings were also reported by Akesowan (2010), Ahmad et al. (2010) and Garcia et al. (2006) in light pork burgers, buffalo meat sausages and reduced-fat sausages, respectively. The treated formulations had significantly $(p<0.01)$ higher overall acceptability scores than the control product. The $T_{3}$ had the highest overall acceptability. It might be due to the improved flavour, juiciness and texture characteristics of the treated sausages (Garcia et al. 2006 and Ahmad et al. 2010).

In the present study, the sensory qualities of both the control and treatment formulations decreased significantly $(p<0.01)$ during the storage period. Reduction in colour score might be due to oxidative fading and non-enzymatic browning (Naveen et al., 2016). At the same time, the flavour deterioration during storage might be attributed to microbial growth and oxidative rancidity (Suresh et al., 2003). Changes in chemical contents such as protein, moisture, fat collagen and $\mathrm{pH}$ value during storage resulted in texture change (Dong et al., 2007). A decrease in all the sensory attributes during storage reflected significantly $(p<0.01)$ lower scores for overall acceptability. The present findings were congruent with the observations of Naveen et al. (2016) in duck meat sausages and Biswas et al. (2011) in duck meat patties.

\section{CONCLUSION}

Based on various physicochemical and organoleptic results, treatment $\mathrm{T}_{3}$ with $2.5 \% \mathrm{SPI}$ and $2.5 \%$ inulin was found to be the best among all the groups. Therefore, low-fat duck meat sausages with superior sensory qualities can be prepared with the addition of $2.5 \%$ soy protein isolate and $2.5 \%$ inulin without affecting the various physicochemical parameters upto $10^{\text {th }}$ days.

\section{ACKNOWLEDGEMENT}

The authors are grateful to the Department of Livestock Products Technology CVSc, AAU, Khanapara and Department of Biotechnology, Govt of India for providing financial support and necessary infrastructure facility to carry out the research work.

\section{Conflict of interest: None.}

\section{REFERENCES}

Ahmad, S., Rizawi, J.A. and Srivastava, P.K. (2010). Effect of soy protein isolate incorporation on quality characteristics and shelf-life of buffalo meat emulsion sausage. J. Food Sci. Technol. 47(3): 290-294.

Akesowan, A. (2010). Quality characteristics of light pork burgers fortified with soy protein isolate. Food Sci. Biotechnol. 19(5): 1143-1149.
Alaei, F., Hojjatoleslamy, M. and Hashemi Dehkordi, S.M. (2018). The effect of Inulin as a fat substitute on the physico chemical and sensory properties of chicken sausages. Food Sci. Nutri. 6(2): 512-519.

Biswas, S. Chakraborty, A. Patra, G. and Dhargupta, A. (2011). Quality and acceptability of duck patties stored at ambient and refrigeration temperature. Int. J. Livest. Prod. 2(1): 1-6.

Bratzler, L.J. (1971). Palatability Factors and Evaluation. In: Science of Meat and Meat Products. [Price, J.F. and Schweiwert, B.S. (eds.)]. W.H. Freeman and Co., San Francisco.

Brewer, M.S. (2012). Reducing the fat content in ground beef without sacrificing quality: A review. Meat Sci. 91: 385395.

Dong, Q.L. Tu, K. Guo, L.Y. Yang, J.L. Wang, H. and Chen, Y.Y. (2007). The effect of sodium nitrite on the textural properties of cooked sausage during cold storage. J. Texture Stud. 38: 537-554.

Fernandez-Gines, J.M., Fernendez-Lopez, J., Sayas-Barbera, E., Perez-Alvarez, J.A. (2005). Meat products as functional foods: A Review. J Food Sci. 70: R37-43. DOI: 10.1111/ j.1365-2621.2005.tb07110.x.

Garcia, M.L. Cáceres, E. and Selgas, M.D. (2006). Effect of Inulin on the textural and sensory properties of Mortadella, A Spanish cooked meat product. Int. J. Food Sci.Technol. 41(10): 1207-1215.

Jairath, G., Sharma, D.P., Dabur, R.S., Singh, P.K. and Bishnoi, S. (2018). Standardization of corn starch as a fat replacer in buffalo calf meat sausages and its effect on the quality attributes. Indian J. Anim. Res. 52: 1521-1525.

Janvary, L. (2008). Replace fat in meat with Inulin. Food Beverage Asia. 15-17.

Kılınççeker, O. and Kurt Ş. (2018). Effects of inulin, carrot and cellulose fibres on the properties of raw and fried chicken meatballs. South African J. Anim. Sci. 48: 39-47.

Kumar, M., Sharma, B.D., Kumar, S. and Sharma, R.B (2004) Shelf life of low-fat ground pork patiies formulated with texturized soy protein. Indian J. Anim. Res. 39: 14-19.

Kumar, V., Biswas, A.K., Sahoo, J., Chatli, K.M. and Sivakumar, S. (2013). Quality and storability of chicken nuggets formulated with green banana and soyabean hull flours. J. Food Sci. Technol. 50: 1058-1068.

Kumar, Y. ( 2019). Development of low-fat/reduced-fat processed meat products using fat replacers and analogues. Food Reviews Int. 37: 296-312. (Published online Dec, 2019).

Lee, C.W., Kim, T.K., Hwang, K.E., Kim, H.W., Kim, Y.B., Kim, C.J. and Cho, Y.S. (2017). Combined effects of wheat sprout and isolated soy protein on quality properties of breakfast sausage. Korean J. Food Sci. An. 37(1): 52.

Matitaputty, P.R., Wijaya, C.H., Bansi, H., Laudadio, V., Tufarelli, V. (2015). Influence of duck species and cross-breeding on sensory and quality characteristics of Alabio and Cihateup duck meat. CyTA-J. Food.13: 522-526.

Mendez Zamora, G.J., Garcia Macias, A., Santellano Esterada, E., Chavez Martinez, A., Duran Melendez, L.A., Silvia Varquez, R., and Quintero Ramos, A. (2015). Fat reduction in the formulation of frankfurter sausages using inulin and pectin. Food Sci. Technol. 53(1): 25-31. 
Effects of Soy Protein Isolate and Inulin on Physico-chemical and Organoleptic Qualities of Low-fat Duck Meat Sausages

Mongale, C.W., Carpenter, J.A. and Reagan, J.O. (1985). The effects of soluble and insoluble components of beef skeletal muscle on the stability of meat batters J. Food Quality. 8: 145-152.

Naveen, Z. Naik, B.R. Subramanyam, B.V. and Reddy, P.M. (2016). Studies on the quality of duck meat sausages during refrigeration. Springer Plus. 5(1): 2061.

Pearson, A.M. and Gillett, T.A. (1996). Processed Meats (Third edn) CBS Publishers and Distributors New Delhi, India. pp-355.

Pippen, E.L., De Fremery, D., Limeweaver, H. and Hanson, H.L. (1965). Chicken broth flavour and pH Poultry Sci. 4: 816.

Strange, E.D. Benedict, R.C. Smith, J.L. and Swift, K. (1977). Evaluation of rapid tests for monitoring alteration in meat quality during storage. J. Food Protect. 40: 843-847.
Suresh, D. Mendiratta, S.K. Anjaneyulu, A.S.R. (2003). Effect of calcium lactateon the quality and shelf life of restructured pork rolls. J. Meat Sci. 1: 1-6.

Wardlaw, E.R., Mc Caskill, L.M. and Acton, J.C. (1973). Effect of post mortem muscle changes on poultry meat loaf properties. J. Food Sci. 38: 421.

Witte, V.C., Krause, G.F. and Barley, M.E. (1970). A new extraction method for determining 2-thiobarbituric acid values for pork and beef during storage. J. Food Sci. 35: 582.

Yadav, S.K. Tanwar, V.K. Sharma, J.K. and Yadav, S. (2013). Effect of added soy protein on physicochemical properties of chevon patties. J.Meat. Sci.Technol. 1(1): 35-39. 